
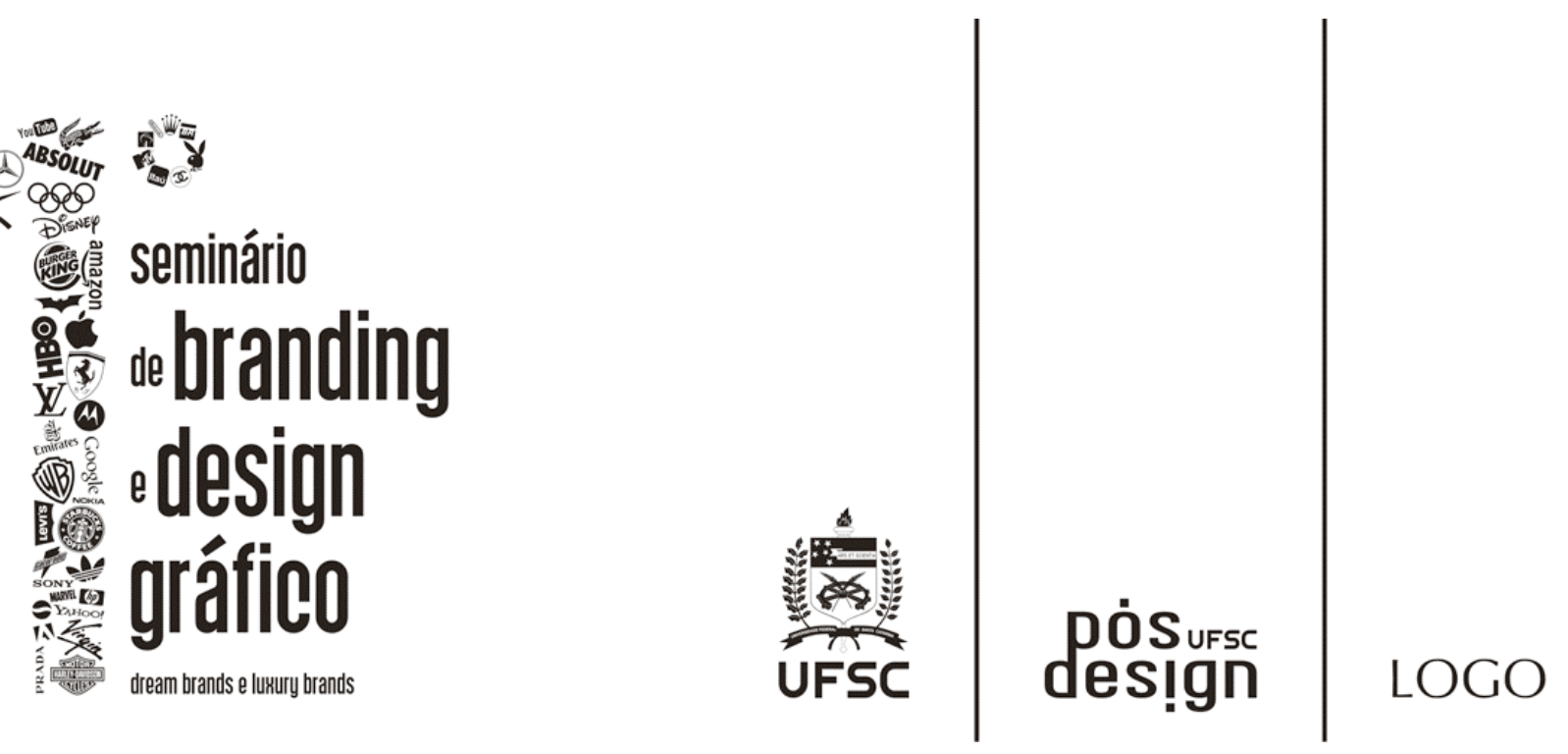

\title{
Sonhar é preciso
}

\section{We need to dream}

GOMEZ, Luiz Salomão Ribas

Doutor em Engenharia - LOGO - PosDesign - UFSC

salomao@logo.ufsc.br

\section{Resumo}

Este artigo relata a participação do Design Gráfico na construção e divulgação das Marcas de Sonho - Dream Brands, o que são, como estão inseridas no mercado e porque encantam os consumidores contemporâneos. Constrói uma definição para Dream Brand baseada em teorias científicas da psicologia e da medicina do sono, contextualiza o universo emocional das marcas e por fim procura definir o papel do Design Gráfico em todo o processo.

Palavras Chave: design gráfico, marca, dream brand

\section{Abstract}

This paper presents the Graphic Design participation in construction and disclosure process of Dream Brands. What they are, how are they insert in market and why are that delight contemporary consumers; shows a Dream Brand definition based on scientific theories of psychology and sleep medicine, context the brand emotional context and in the and define the Graphic Design function in this process.

Keywords: graphic design, brand, dream brand

"Navegar é preciso; viver não é preciso".

(Fernando Pessoa) 


\section{DREAM BRAND}

Realmente pode haver uma relação direta entre os sonhos e o nosso comportamento? Na psicanálise a resposta para essa pergunta é simples: SIM. Porém, muitos pesquisadores que estudam os mecanismos cerebrais dos sonhos refutam a idéia de que essas imagens ou sons possam ter ligação com nossos atos diários. Para Sérgio Tufik, Vice-Reitor da UNIFESP e diretor do Instituto do Sono, no entanto, a teoria é muito plausível. "O sonho é um espelho que nos reflete", afirma Tufik. "Estudamos cada vez mais os mecanismos neurológicos, mas acredito que o sonho pode refletir nossos conflitos, angústias e ansiedades", completa ${ }^{1}$.

Então, parafraseando o poeta com uma adequação ao que os antigos marinheiros diziam: "Sonhar é preciso, viver não é preciso." Com o crescimento da sociedade de consumo e as novas formas de participação na sociedade, agora organizada em "tribos", onde o status e a participação efetiva nas atividades comuns entre os pares são de suma importância para que o cidadão comum posso efetivamente dizer que faz parte dela, cada dia mais os sonhos se aproximam dos objetos de consumo. Não é raro ouvir que este ou aquele "produto" é o SONHO DE CONSUMO de alguém não importando a "tribo" a que esse consumidor faz parte ou se identifica.

As corporações perceberam isso já a algumas décadas e têm procurado construir marcas que façam parte dos sonhos de todos os consumidores. Querer, na maioria das vezes, não é poder, porém, o desejo de consumir e de conquistar o seu SONHO DE CONSUMO, faz com que as pessoas estabeleçam metas econômicas ou financeiras para tornar realidade essa sua vontade especial. Sendo assim, uma marca que se torna desejada por um grande número de consumidores que a vêem como um degrau a mais na sua escala social dentro da "tribo" que participa, pode ser considerada uma DREAM BRAND.

\section{UNIVERSO EMOCIONAL DAS MARCAS}

As marcas são, acima de tudo, idéias e conceitos. Conceitos que estão apoiados em questões concretas, de pessoas que acreditam profundamente nos seus produtos ou nos seus serviços, naqueles que existem ou naqueles que estão a criar. Muito mais que uma imagem representada por um logotipo, as marcas conseguem acessar o imaginário das pessoas. Para Kotler e Keller (2006, p. 269) as marcas

\footnotetext{
${ }^{1}$ Retirado do artigo "Sonhar é preciso", de Regiane Monteiro publicado no Jornal "Diário de SP" - Caderno "Viver em Família" em $03 / 11 / 2002$
} 
[...] identificam a origem ou o fabricante de um produto e permitem que os consumidores - sejam indivíduos ou Empresas - atribuam a responsabilidade pelo produto a determinado fabricante ou distribuidor. Os consumidores podem avaliar um produto idêntico de forma diferente, dependendo de como sua marca é estabelecida.

Para Nunes (2003, p. 17), “[...] marcas são entidades constituídas essencialmente por aspectos intangíveis de percepção e valor que habitam a mente e o coração do usuário, do cliente, do consumidor final", o que vem a estabelecer um posicionamento coincidente com a visão de Martins (1999), que define a marca como uma entidade com personalidade independente, aonde a parte mais sensível em sua construção é a formação das características emocionais que vai carregar.

Cada dia que passa a relevância das marcas se faz mais presente para o consumidor, que entrar no supermercado ou em um shopping center, ao abrir o jornal ou ligar a televisão é bombardeado por uma "saraivada" de marcas. Diariamente surgem novas marcas, segundo o INPI (Instituto Nacional de Propriedade Intelectual), são protocolados cerca de 30.000 novos pedidos de registro me marcas por ano no Brasil e atualmente essas marcas têm sido a maioria no setor de serviços, mais especificamente nas telecomunicações e tecnologias. Isso mostra que tanto marcas "reais" quanto "virtuais" têm entrado cotidianamente no UNIVERSO DAS MARCAS.

O grande objetivo dessas marcas é conquistar consumidores e, de preferência, que se tornem fiéis a elas. Alguns autores como Kevin Roberts em seu livro LOVEMARKS (2005) descrevem que as marcas precisam criar em seus consumidores "fidelidade além da razão", construir uma relação de amor, de paixão, uma relação mais que física, atingindo o emocional das pessoas. Roberts chega ao ponto de construir um gráfico de correlação entre as marcas e sua percepção entre os consumidores (fig.1).

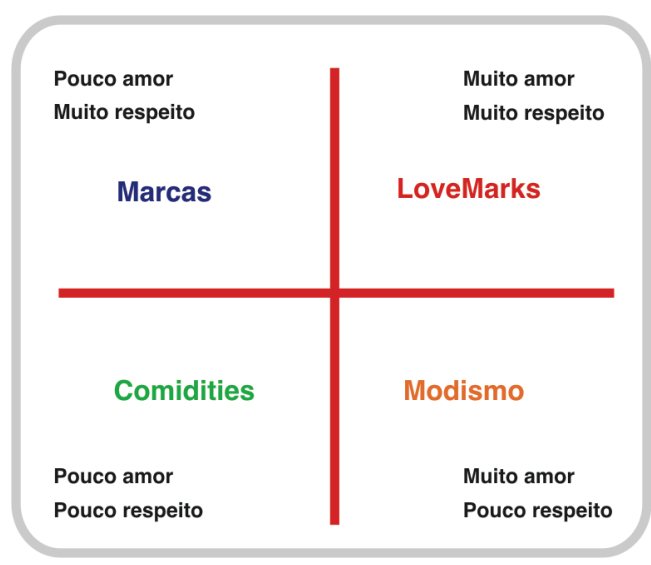

Fig. 1 - LoveMarks

Fonte: (Roberts, K. 2005) 
Amar uma marca pode parecer algo um pouco estranho, principalmente para os latinos que são muito passionais e vêem o amor como algo de suprema importância na sua vida. Porém, a nova sociedade de consumo tem se apegado cada vez mais a bens materiais para justificar suas atitudes capitalistas de uso perdulário do dinheiro adquirido com (ou sem) suor do seu rosto. As corporações já perceberam isso e têm colocado cada vez mais e mais apelos emocionais nas estratégias de vendas de seus produtos.

Utilização de estratégias publicitárias, sejam de marketing ou endomarketing pelas empresas, como a divulgação das suas ações de responsabilidade social, ecológica e até mesmo fiscal, campanhas que mostrem a família, a saúde e a igualdade de classe, crenças e raças - tem mexido com o emocional dos consumidores convidando-os a sonhar acordado com a aquisição de MARCAS que ele ame ou, no mínimo, possa estar apaixonado.

\section{SONHAR ACORDADO}

Quando piscamos mais demoradamente até nos sentirmos num estado que podemos considerar semi-letárgico podemos dizer que entramos em REM, abreviatura inglesa para "movimentos rápidos dos olhos" (Fernandes, 2006). Nesse momento rápido, diversos pensamento são formados no imaginário humano, pode-se dizer que estamos "sonhando acordados".

Toda pessoa tem esse momento de "sonho acordado", é cientificamente comprovado. Neste momento o imaginário leva o consumidor, no caso, a construir relação com "coisas" que sejam de seu interesse criando o desejo de consumi-las por uma necessidade de realizar o sonho daquele momento. É lógico que não apenas quando se realiza um REM ou se tira um "soneca" os sonhos de consumo surgem no imaginário, eles estão se formando a todo momento no cérebro e apenas esperando o momento certo de se manifestar como um desejo a ser realizado.

Elisa Piedras (2006) em seu estudo de publicidade baseada em teorias expostas por Lipovetsky e Mafessoli, entre outros conclui que:

"Com base no referencial teórico e nos dados coletados e analisados qualitativamente, podemos afirmar que as mulheres pesquisadas (as quais de fato consomem mais que os homens) concebem o sonho como algo imaterial, enquanto o "sonho de consumo" remete geralmente a um objeto material. Para elas, a banalidade das conversas e ruas, e a publicidade são os palcos onde "sonho de consumo" se torna presente."

Um sonho muitas vezes pode parecer algo inatingível. Porém, não impossível de conquistar se existir determinação e persistência. Muitas vezes os sonhos e principalmente os de consumo 
podem ser alcançados facilmente quando se estabelece ele como meta ou forma de realização pessoal. Fazer parte de uma "tribo" está cada vez mais comum e mais fácil de acontecer. Sonhar ter um iPhone, ou uma Harley Davidson, ou ainda, assistir aquele filme ou jantar naquele restaurante é muito comum entre os consumidores e com as mudanças na economia, globalização e, infelizmente, contrabando e pirataria, realizar esses sonhos está cada vez mais fácil.

Como "Sonhar é Preciso", resta as marcas encontrarem o caminho certo para atingir o emocional dos consumidores e assim conquistara seus corações. Novamente parafraseando a cultura popular que diz que o "caminho do coração passa pelos olhos" ou ao poeta que disse "me desculpem as feias mas beleza é fundamental", , as marcas precisam primeiramente conceituar-se bem porém, de nada adianta se não se apresentarem bem. Então para fazer parte dos sonhos dos consumidores as marcas precisam de uma imagem visual e gráfica adequada que possa remeter às suas qualidades, habilidades, competências e ao seu diferencial perante as dezenas, centenas ou talvez milhares de concorrentes a participar desse sonho.

\section{E O DESIGN GRÁFICO?}

O profissional do design gráfico conta com uma ampla gama de atividades para desenvolver e atuar junto a gestores de marca na criação de valor para marcas e produtos. Segundo o Centro Português de Design (1997, p.34), “os designers gráficos são especialistas na criação de elementos que permitem uma determinada identificação e diferenciação dos aspectos visuais da empresa, contribuindo, por meio deles, para a política e estratégia de comunicação da mesma.”

De acordo com Strunk (2003), marca é um nome, normalmente representado por um desenho (logotipo e/ou símbolo), que, com o tempo, devido às experiências reais ou virtuais, objetivas ou

subjetivas que vamos relacionando a ela, passa a ter um valor específico. É um artigo intangível, cuja vida é indeterminada, desde que bem administrada por seus gestores.

Usando esses dois conceitos para encontrar a participação do Design Gráfico no processo de construção e promoção de marcas afim de transformá-las em Dream Brands, pode se ter a clara noção da importância de sua participação. Criar os elementos de identificação adequados baseado em informações subjetivas pode ser considerada a forma mais efetiva de apoio a fixação das marcas no pensar do consumidor. A imagem apresentada no cotidiano nas mais diversas formas como em mídias, nas embalagens, nas vitrines, entre outros, entra no imaginário das pessoas fazendo-as sonhar com a possibilidade de ter ou usar aquela marca. 
E, quando se fala em imagem, o poder do Design Gráfico se torna evidente. É lógico que o Design Gráfico não consegue apenas com sua competência em uso das formas visíveis transformar qualquer marca em sonho. Porém, apoiado nos conceitos mais amplos, como o de DNA de marca ${ }^{3}$ (Coelho e Rocha, 2007) e por informações obtidas de outros profissionais como os de comunicação e os de marketing, é muito provável que uma marca bem trabalhada consiga construir um conceito comercial afetivo com seu consumidor ou pretenso consumidor, não importando se é de um produto, um serviço ou qualquer outra coisa, sendo cara ou barata, podendo ser chamada de DREAM BRAND.

\section{REFERÊNCIAS}

AAKER, David A; JOACHIMSTHALER, Erich. Como Construir Marcas Líderes. Porto Alegre: Bookman, 2007.

CEntro De DeSign PORTuguÊS. Manual de Gestão de Design. Porto: DZ Centro de Diseño, 1997.

CHEVAlier, Michel; MAZZAlovo, Gérald. Pró Logo. Marcas como Fator de Progresso. Tradução: Roberto Galman. São Paulo: Panda Books, 2007.

GOBÉ, Marc. A emoção das marcas: conectando marcas às pessoas. Rio de Janeiro: Campus, 2002.

COELHO, Carlos; ROCHA Paulo. Brand Taboos. Os segredos por detrás das marcas que, até hoje, ninguém se atreveu a explicar. 1.ed. Lisboa: Booknomics, 2007.

Fernandes RMF. O sono normal. Medicina (Ribeirão Preto) 2006; 39 (2): 157-168.

GOMEZ, L. S. R.; SILVA, G.G. Visual Communication Branding. In: Design \& cc: SOS!

Design and Commercial Comunications: Seek Optimal Synergies: Lisboa, 2007.

KOTLER, Philip e KELLER, Kevin L. Administração de Marketing. São Paulo: Pearson Prentice Hall, 2006.

LINDSTROM, Martin. Brand sense: A Marca Multissensorial. Porto Alegre: Bookman, 2007.

2 Frase atribuída a Vinícius de Moraes, Poeta Brasileiro do século XX

3 O "DNA" da marca refere-se ao seu caráter distintivo, novidade e atributos, quando comparados com a concorrência. 
MARTINS, José R. A natureza emocional da marca: como escolher a imagem que fortalece a sua marca. São Paulo: Negócio Editora, 1999.

NUNES, Gilson. Marca: valor do intangível, medindo e gerenciando seu valor econômico. São Paulo: Atlas, 2003.

PIEDRAS, Elisa. SONHO DE CONSUMO: a publicidade na intersecção entre o consumo material e o simbólico, pelo olhar do receptor. XV Encontro da Compós, na Unesp, Bauru, SP, junho de 2006.

ROBERTS, Kevin Lovemarks: o Futuro Além das Marcas. São Paulo: M. Books, 2005.

STRUNK, Gilberto. Como criar identidades visuais para marcas de sucesso: um guia sobre o marketing das marcas e como representar graficamente seus valores. $2^{\mathrm{a}}$ ed. Rio de janeiro: Rio Books, 2003. 